\title{
Employment loss during economic crisis and suicidal thoughts in Belgium:
}

\author{
a survey in general practice
}

\begin{abstract}
Background

The economic crisis of 2009 led to a wave of corporate reorganisations and bankruptcies, with many dismissals of employees. GPs were confronted with subsequent health consequences.
\end{abstract}

\section{Aim}

To assess the possible relationship between losing one's job and having suicidal thoughts.

\section{Design and setting}

A survey of patients aged 18-49 years recruited from GP practices in Belgium in Deurne (Flemish region) and La Louvière (Walloon region) from September to December 2010

\section{Method}

Anonymous self-administered questionnaire.

\section{Results}

Of all eligible patients ( $n=1818$ ), 831 were offered the questionnaire and 377 completed it ( $45.4 \%)$. More than one in five had been confronted with employment loss in the past year (the responder or someone close losing their job). Almost one in ten had lost their job themselves in the past year. More than one in four had experienced suicidal thoughts and $11.7 \%$ had seriously considered ending their life in the past year. In the logistic regression analysis, the following characteristics showed a statistically significant relationship with having suicidal thoughts: being single lodds ratio $[\mathrm{OR}]=4.8,95 \%$ confidence interval $[\mathrm{Cl}]=1.7$ to 13.8$)$, not having satisfying social contacts $(\mathrm{OR}=5.1,95 \% \mathrm{Cl}=1.6$ to 16.2$)$, having depressive complaints $(\mathrm{OR}=18.4,95 \% \mathrm{Cl}=5.8$ to 58.4 ), and having lost one's employment in the past year $(\mathrm{OR}=8.8,95 \% \mathrm{Cl}=2.0$ to 39.3$)$.

\section{Conclusion}

This study points to a statistically significant relationship between losing one's employment in the past year and having suicidal thoughts. It emphasises the important role of the GP in the continuous and reinforced assessment of suicidal risk in times of recession.

\section{Keywords}

Belgium; economic recession; employment termination; general practice; suicidal ideation.

\section{INTRODUCTION}

In 2009, the Belgian labour market was hit by the worst financial economic crisis in decades. The large number of corporate restructures and bankruptcies led to a significant level of labour force dismissals. Little is known about the precise impact this ongoing crisis has had on people's health. However, data on the Flanders region show that major increases in unemployment rates during this crisis were associated with a significant increase in suicide rates. ${ }^{1}$ This is confirmed by data from other countries in the European Union. ${ }^{2}$ Unfortunately, the Network of Sentinel General Practitioners (GPs) in Belgium was not asked to register suicidal behaviour in 2009 and 2010. ${ }^{3}$ This was a missed opportunity for analysing the link between the economic crisis and suicidal behaviour.

Since the outbreak of the current global financial and economic crisis, the need and demand for a wider perspective on people's health from practitioners and policy makers has substantially increased. ${ }^{4,5}$ In general, front-line health workers, and GPs in particular, have the ongoing task and privilege of following and guiding their patients through stressful life events. Employment loss and job insecurity can be highly stressful events. GPs should be able to detect and evaluate the impact of such events on people's lives and health, and act when necessary. In undergraduate medical education in Belgium, however, only a few hours are given to formal instruction on mental health in relation to occupational medicine. ${ }^{6}$

F Vanderoost, MD, GP; S van der Wielen, MD, GP, Medics For The People, Belgium. K van Nunen, MSc; G Van Hal, PhD, Professor, Medical Sociology and Health Policy, University of Antwerp. Belgium.

\section{Address for correspondence}

Guido Van Hal, University of Antwerp,

Universiteitsplein 1, 2610 Wilrijk, Belgium.
Suicidal thoughts are a key stage in the pathway leading to suicide. A large World Health Organization international mental health survey showed that roughly one-third of people who mention having had suicidal thoughts over the past 12 months develop a suicide plan, and around $15-20 \%$ make a suicide attempt. ${ }^{7}$ More than $60 \%$ of the transitions from suicidal thoughts to suicide attempt occur in the first year after the onset of these thoughts. ${ }^{7}$ Enquiring about suicidal thoughts during the clinical encounter with the patient can be an important tool and a first step in an intervention aimed at reducing the risk of suicide. A greater understanding of the social, psychological, and treatment-related factors influencing their development and improvement could benefit suicide-prevention strategies. ${ }^{8}$

The National Health Interview Survey of Belgium in 2008 (HIS) showed that 3.1\% of the population had experienced suicidal thoughts in the past 12 months. ${ }^{9}$ Only a few studies have prospectively investigated the incidence of suicidal thoughts. One study observed an almost fourfold greater risk of developing suicidal thoughts in people who had lost their job during an 18-month follow-up, compared with those who remained employed. The difference was not significant. ${ }^{8}$ Increased incidence was associated with not being in a stable relationship, low levels of social support, and being unemployed. The most important risk factor is the presence of a psychiatric condition. Several cross-sectional studies have documented the prevalence of, and risk factors for, suicidal thoughts, with

E-mail: guido.vanhalduantwerp.be Submitted: 31 December 2012; Editor's response: 7 March 2013; final acceptance: 7 May 2013. (CBritish Journal of General Practice

This is the full-length article (published online 30 Sep 2013) of an abridged version published in print. Cite this article as: Br J Gen Pract 2013; DOI: 10.3399/bjgp13X673702 


\section{How this fits in}

Since the recent severe economic crisis in Greece, the link between a bad economic situation and suicidal thoughts and suicide has become highly topical. However, in countries that have not been hit as deeply as Greece by the economic recession, the question of the influence of the economic crisis on the mental health of the population is also raised increasingly. Several studies have shown that unemployment is associated with suicidal thoughts but few have focused on employment loss specifically. This study investigated the impact of employment loss on suicidal thoughts in individuals in Belgium, and the implications of this for GPs' daily practice.

similar results. ${ }^{10-15}$ None of them, however, has investigated the association between recent employment loss or job insecurity and suicidal thoughts.

The aim of this cross-sectional study is to identify independent risk factors for suicidal thoughts in two GP practices in Belgium during the economic crisis. The study focuses on adults of potential economically active age and on occupationally related factors.

\section{METHOD}

From September to December 2010, a cross-sectional health survey was conducted in two urban general practices in Belgium: Deurne in the Flemish Region (about 3000 patients) and La Louvière in the Walloon Region (about 1000 patients), both operating a multidisciplinary team with several GPs, administrative and reception staff, nurses, and volunteers. They both operate a capitation system. At the time of the survey, two of the authors each worked in one of these centres as a resident physician. In Belgium, only a small, though increasing, proportion of GPs are financed via a capitation system. ${ }^{16}$ In general, the population affiliated to a capitation system in Belgium is younger and has a lower socioeconomic status than the average Belgian population. ${ }^{17-19}$ Belgian GPs attempt, with variable success, to act as a gatekeeper in the health system. Patients, however, are free to use secondand third-line levels of care on their own initiative.

A self-administered questionnaire was used to acquire insight in the selfrated health status of the patient and to investigate a number of work-related topics. The main study questions were: 'have you ever seriously thought of ending your life and did you have such thoughts in the past 12 months?', and 'Were you confronted with employment loss among your family and close friends during the past year? If so, who lost their job and for what reason?.

The subjective assessment of health reliably reflects the health problems the responders are facing and it is closely related to mortality, morbidity, level of functional ability, and medical consumption. ${ }^{9}$ Moreover, there is evidence that reports of potentially embarrassing behaviours are higher in self-administered than in interviewer-administered surveys. ${ }^{7,20}$

The written questionnaire was available in Dutch and French. The back-translation method was used to ensure consistency. Candidates who did not have sufficient knowledge of French or Dutch were excluded from the study.

The majority of the questions in the survey were validated questions drawn from the HIS; other questions were constructed around or based upon them. The survey gathered self-administered information on morbidity, health status, health-related behaviours, and use of healthcare services, as well as sociodemographic data.

The International Standard Classification of Education (ISCED) 2011 was used to classify educational level, with a high education level being ISCED level 6 to 8; Low education level being ISCED level 3 to 5 ; and minimal education being ISCED level 0 to 2.21

For depressive complaints, a valid subscale of the Symptom Checklist was used. The higher the score, the worse the health problem. This scale also takes chronic problems into account.

The survey was presented in the form of a question booklet. The outer leaf contained the title page ('Health questionnaire in general practice'), a brief introduction, and a request for informed consent. The introduction did not refer to the economic crisis or to suicidal thoughts. Anonymity was guaranteed by separating the outer leaflet from the rest of the booklet.

It was decided to use a selection based on age. The survey focused on adults of potential economically active age ( $\geq 18$ years) and all individuals aged $>49$ years were excluded from the study population, because of the higher risk of confounding health problems. ${ }^{22-25}$

The statistical practice programme StatDPPRO ${ }^{\circledR}$ of electronic health record Medidoc $^{\circledR}$ isolated a total of 1818 potential responders, of whom 1225 were in Deurne 


\begin{tabular}{lc}
$\begin{array}{l}\text { Table 1. Sociodemographic } \\
\text { characteristics of all }\end{array}$ \\
responders ( $\boldsymbol{n}=377)$ \\
\hline Characteristic & $\%(\boldsymbol{n})$ \\
\hline Sex & \\
Male & $36.6(138)$ \\
Female & $63.4(239)$ \\
\hline Age in years & \\
18-25 & $25.2(95)$ \\
$26-39$ & $37.7(142)$ \\
40-49 & $36.9(139)$ \\
No information & $0.2(1)$ \\
\hline Social situation & \\
Single, no children & $17.5(66)$ \\
Single, children & $12.5(47)$ \\
Partner, no children & $13.5(51)$ \\
Partner, children & $49.4(186)$ \\
Still living with parents & $6.6(25)$ \\
No information & $0.5(2)$ \\
\hline Highest level of education & \\
Minimal & $27.3(103)$ \\
Low & $48.5(183)$ \\
High & $19.9(75)$ \\
No information & $4.3(16)$ \\
\hline Social contacts & \\
Satisfying & $79.3(299)$ \\
Not satisfying & $15.7(59)$ \\
No information & $5.0(19)$ \\
\hline
\end{tabular}

and 593 in La Louvière.

From September to December 2010, all eligible candidates who came to one of the health centres were invited to fill in the questionnaire. The invitation was offered

\section{Table 2. Employment characteristics of all responders $(n=377)$}

\begin{tabular}{lc} 
Characteristic & $\%(\boldsymbol{n})$ \\
\hline Occupation & \\
Paid occupation & $48.8(184)$ \\
No paid occupation & $47.2(178)$ \\
No information & $4.0(15)$ \\
\hline
\end{tabular}

Confronted with employment loss in the past year (the responder or someone close)

No

$74.0(279)$

Yes

$21.8(82)$

No information $4.2(16)$

Employment loss in the past year (the responder)

\begin{tabular}{lc} 
No & $83.8(316)$ \\
Yes & $9.6(36)$ \\
No information & $6.6(25)$ \\
\hline Able to make ends meet & \\
Easily & $36.1(136)$ \\
With difficulty & $57.0(215)$ \\
No information & $6.9(26)$ \\
\hline
\end{tabular}

during consultation by a doctor or a nurse, or in the waiting room by the reception staff. All visiting patients were encouraged to hand out questionnaires to family members, with a telephone reminder halfway through the survey period. Further mobilisation was done by patient newsletters.

After cleaning, the data were analysed using the programme SPSS $15.0^{\circledR}$ for Windows.

Data from both practice populations were analysed together. Simple frequencies and bivariate and multivariate analyses were performed when relevant and appropriate. The bivariate analyses used $\chi^{2}$ tests, and the multivariate analysis was a logistic regression. Statistical significance was tested at a 5\% probability level.

\section{RESULTS}

In total, 831 eligible candidates received a questionnaire, of whom 377 responded (261 in Flanders and 116 in Wallonia, response rate $45.4 \%$ ). Table 1 shows the sociodemographic characteristics of the responders. The mean age of all responders was 34.6 years. Overall, $61.8 \%(n=233 / 377)$ had at least one child.

Table 2 shows the employment characteristics of the responders and whether they were able to make ends meet. The responders without a paid occupation I $n=178)$ were mostly unemployed $(34.3 \%$; $n=61 / 178)$, still studying (18.5\%; $n=33 / 178)$, or receiving benefit (sickness or disability benefit, a pension or social security; $26.4 \%$; $n=47 / 178$ ), or the household was receiving no benefits at all (12.4\%; 22/178). For $8.4 \%$ ( $n=15 / 178$ ), there was no information. Of the responders who were unemployed ( $n=61), 32.8 \%(n=20 / 61)$ had lost their job during the past year; the other $57.4 \%$ (35/61) were long-term unemployed. For $9.8 \%(n=6 / 61)$, there was no information. Of those with a paid occupation ( $n=184)$, $16.3 \%$ ( $n=30 / 184)$ faced job insecurity, and $81.5 \%$ did not ( $n=150 / 184$ ). For $2.2 \%$ ( $n=4 / 184)$, there was no information regarding this topic.

Table 3 shows some health characteristics of all responders.

More than one in four (26.0\%; $n=98 / 377$ ) had ever had suicidal thoughts; $70.0 \%$ I $n=264 / 377$ ) had never had suicidal thoughts; and for $4.0 \%(n=15 / 377)$ there was no information. Of all responders, $11.7 \%(n=44 / 377)$ had seriously considered making an end to their life in the past 12 months; 83.0\% ( $n=313 / 377)$ had not considered this; and for $5.3 \%(n=20 / 377)$. there was no information.

The bivariate analysis points to an increase 
Table 3. Self-rated health and depressive complaints of all responders $(n=377)$

\begin{tabular}{lc} 
Health & $\%(\boldsymbol{n})$ \\
\hline Self-rated health & \\
Good & $58.1(219)$ \\
Neutral & $31.3(118)$ \\
Bad & $9.0(34)$ \\
No information & $1.6(6)$ \\
\hline Depressive complaints & \\
Average or below average & $61.5(232)$ \\
Above average & $19.9(75)$ \\
No information & $18.6(70)$ \\
\hline
\end{tabular}

in suicidal thoughts among responders with the following characteristics: being single, having difficulty making ends meet, not having satisfying social contacts, having poor self-rated health, having lost one's employment in the past year, having had to cope with job insecurity, and having depressive complaints. No statistically significant association was found between suicidal thoughts and age, sex, education, or confrontation with employment loss of someone close (Table 4).

To identify the factors influencing suicidal thoughts, a logistic regression model was constructed, with suicidal thoughts (dichotomous) as the dependent variable, and the selected independent variables that showed statistical significance in the $\chi^{2}$

\section{Table 4. Factors associated with suicidal thoughts: bivariate analyses (presented for the sample with complete data on all variables; $n=251$ )}

\begin{tabular}{|c|c|c|c|c|c|c|}
\hline \multirow[b]{3}{*}{ Characteristic } & \multicolumn{4}{|c|}{ Suicidal thoughts } & \multirow[b]{3}{*}{$P$-value ${ }^{a}$} & \multirow{3}{*}{$\begin{array}{l}\text { Odds ratio } \\
\text { (95\% CI] }\end{array}$} \\
\hline & \multicolumn{2}{|c|}{ Yes } & \multicolumn{2}{|c|}{ No } & & \\
\hline & $n$ & $\%$ & $n$ & $\%$ & & \\
\hline \multicolumn{7}{|l|}{ Age in years } \\
\hline $18-25^{b}$ & 10 & 14.5 & 59 & 85.5 & 0.363 & - \\
\hline $26-39$ & 8 & 9.1 & 80 & 90.9 & & $1.7(0.6$ to 4.5$)$ \\
\hline $40-49$ & 15 & 16.0 & 79 & 84.0 & & $0.9(0.4$ to 2.1$)$ \\
\hline \multicolumn{7}{|l|}{ Sex } \\
\hline Male & 9 & 10.5 & 77 & 89.5 & 0.364 & $0.7(0.3$ to 1.5$)$ \\
\hline Female $^{b}$ & 24 & 14.5 & 141 & 85.5 & & - \\
\hline \multicolumn{7}{|l|}{ Highest level of education } \\
\hline Minimalb & 8 & 11.4 & 62 & 88.6 & 0.810 & - \\
\hline Low & 18 & 14.5 & 106 & 85.5 & & 0.7 (0.3 to 1.8) \\
\hline High & 7 & 12.3 & 50 & 87.7 & & 0.9 (0.3 to 2.7) \\
\hline \multicolumn{7}{|l|}{ Being single } \\
\hline Yes & 19 & 24.7 & 58 & 75.3 & $<0.001$ & $3.7(1.8$ to 7.9$)$ \\
\hline $\mathrm{No}^{\mathrm{b}}$ & 14 & 8.0 & 160 & 92.0 & & - \\
\hline \multicolumn{7}{|l|}{ Able to make ends meet } \\
\hline Easily & 6 & 5.5 & 103 & 94.5 & 0.002 & $0.2(0.1$ to 0.6$)$ \\
\hline With difficulty & 27 & 19.0 & 115 & 81.0 & & - \\
\hline \multicolumn{7}{|l|}{ Social contacts } \\
\hline Satisfying & 18 & 8.4 & 196 & 91.6 & $<0.001$ & 0.1 (0.1 to 0.3$)$ \\
\hline Not satisfying & 15 & 40.5 & 22 & 59.5 & & - \\
\hline \multicolumn{7}{|l|}{ Depressive complaints } \\
\hline Average or below average & 7 & 3.7 & 183 & 96.3 & $<0.001$ & $0.0(0.0$ to 0.1$)$ \\
\hline Above average $e^{b}$ & 26 & 42.6 & 35 & 57.4 & & - \\
\hline \multicolumn{7}{|l|}{ Self-rated health } \\
\hline Good $^{b}$ & 10 & 6.8 & 138 & 93.2 & 0.001 & - \\
\hline Neutral & 16 & 20.0 & 64 & 80.0 & & 0.3 (0.1 to 0.7 ) \\
\hline Bad & 7 & 30.4 & 16 & 69.6 & & 0.2 (0.0 to 0.5$)$ \\
\hline \multicolumn{7}{|c|}{ Confronted with employment loss in the past year (the responder or someone close) } \\
\hline No & 21 & 11.0 & 170 & 89.0 & 0.072 & $0.5(0.2$ to 1.1$)$ \\
\hline Yes $^{b}$ & 12 & 20.0 & 48 & 80.0 & & - \\
\hline \multicolumn{7}{|c|}{ Employment loss in the past year (the responder) } \\
\hline No & 23 & 10.4 & 198 & 89.6 & $<0.001$ & $0.2(0.1$ to 0.5$)$ \\
\hline Yes $^{b}$ & 10 & 33.3 & 20 & 66.7 & & - \\
\hline \multicolumn{7}{|l|}{ Job status } \\
\hline No job insecurity ${ }^{b}$ & 7 & 6.1 & 108 & 93.9 & 0.009 & - \\
\hline Job insecurity & 6 & 28.6 & 15 & 71.4 & & 0.2 (0.0 to 0.5$)$ \\
\hline $\begin{array}{l}\text { No paid occupation, available } \\
\text { for labour market (unemployed) }\end{array}$ & 6 & 15.0 & 34 & 85.0 & & 0.4 (0.1 to 1.2$)$ \\
\hline $\begin{array}{l}\text { No paid occupation, currently } \\
\text { not available for labour market } \\
\text { (housewife, on benefits, } \\
\text { disability, etc) }\end{array}$ & 14 & 18.7 & 61 & 81.3 & & 0.3 (0.1 to 0.7$)$ \\
\hline
\end{tabular}




\begin{tabular}{|c|c|c|}
\hline Independent variable & $P$-value & Odds ratio $(95 \% \mathrm{CI})$ \\
\hline \multicolumn{3}{|l|}{ Being single } \\
\hline Yes & 0.003 & $4.8(1.7$ to 13.8$)$ \\
\hline $\mathrm{No}^{\mathrm{b}}$ & & - \\
\hline \multicolumn{3}{|l|}{ Able to make ends meet } \\
\hline Easilyb & & - \\
\hline With difficulty & 0.127 & $2.7(0.8$ to 9.4$)$ \\
\hline \multicolumn{3}{|l|}{ Social contacts } \\
\hline Satisfying ${ }^{b}$ & & - \\
\hline Not satisfying & 0.005 & $5.1(1.6$ to 16.2$)$ \\
\hline \multicolumn{3}{|l|}{ Depressive complaints } \\
\hline Average or below average ${ }^{b}$ & & - \\
\hline Above average & $<0.001$ & $18.4(5.8$ to 58.4$)$ \\
\hline \multicolumn{3}{|l|}{ Self-rated health } \\
\hline$G_{0 o d^{b}}$ & & - \\
\hline Neutral & 0.300 & $1.8(0.6$ to 5.6$)$ \\
\hline Bad & 0.758 & $0.8(0.2$ to 3.9$)$ \\
\hline \multicolumn{3}{|l|}{ Employment loss in the past year (the responder) } \\
\hline $\mathrm{No}^{b}$ & & - \\
\hline Yes & 0.004 & 8.8 (2.0 to 39.3$)$ \\
\hline \multicolumn{3}{|l|}{ Job status } \\
\hline No job insecurity ${ }^{b}$ & & - \\
\hline Job insecurity & 0.990 & $1.0(0.2$ to 6.1$)$ \\
\hline No paid occupation, available for labour market (unemployed) & 0.302 & $0.4(0.1$ to 2.2$)$ \\
\hline $\begin{array}{l}\text { No paid occupation, currently not available for labour market } \\
\text { (housewife, on benefits, disability, etc) }\end{array}$ & 0.822 & $1.2(0.3$ to 4.2$)$ \\
\hline
\end{tabular}

analyses. In logistic regression analyses, being single or not, social contacts, depressive feelings, and employment loss in the past year appeared to be important predictors of suicidal thoughts $(P<0.05)$ (Table 5).

\section{DISCUSSION}

\section{Summary}

People who are single have significantly more suicidal thoughts compared to those who are not. Other studies found comparable results, although less pronounced. ${ }^{8,26}$

Having a negative judgement of one's own social contacts is significantly associated with suicidal thoughts, an association which is consistent with findings in other studies. ${ }^{27}$

The reporting of depressive symptoms is also significantly associated with suicidal thoughts. Several cross-sectional studies have shown the link with depression. 7.11

The last significant association is having lost one's employment during the past 12 months. Several studies have shown that unemployment is associated with suicidal thoughts but, to the study's knowledge, there is only one study, apart from the present one, that has focused specifically on employment loss. ${ }^{8}$ This prospective study by Gunnel et al showed a fourfold greater risk of developing suicidal thoughts for people who lost their job between the baseline and the follow-up interview. The association was not significant.

\section{Strengths and limitations}

This study focuses on the impact of employment loss at the individual level, which had not previously been investigated during the current economic crisis. There is a good chance that this crisis reinforces the negative health effects of employment loss. Moreover, as discussed earlier in the Method section, in Belgium the capitation system seems to attract the population that is most at risk of having adverse health effects due to the economic crisis, namely people of a lower socioeconomic status. ${ }^{17-19,27}$ The other individual-level study on employment loss was undertaken in economically more favourable conditions in 
a general population, which could explain its non-significant association. ${ }^{8}$ Other studies on this current economic crisis were conducted at an aggregate level. The present study was not subsidised. Recruitment of responders was based on an additional voluntary effort of the staff and patients. Given these circumstances, the number of responders reached is quite remarkable. In part this can be explained by the fact that in both practices, many patients are actively involved in the daily functioning of their health facility.

Some important limitations should, however, be kept in mind when interpreting the results of this study.

The cross-sectional design of the study does not allow for a judgement on causality. To the authors' knowledge, there are few prospective studies concerning suicidal thoughts. ${ }^{8,28}$

The study analysis was based on retrospective self-administered data, and therefore potentially contains recall bias and reporting bias. This concern is limited somewhat by the focus on suicidal thoughts in the past 12 months only and by the use of validated questions.

The confidence intervals are wide, owing to the rather small number of responders. A number of factors might not have reached the level of statistical significance because of this.

Suicide-related thoughts and behaviours are likely to be under-reported because of the stigma that might be present.

Although significant efforts were made to carefully translate and back-translate the survey in this study, there may have been differences between the two health centres when reporting on suicidal thoughts and in the interpretation of items assessing risk factors.

External validity is largely reduced by the fact that the response rate was low, coupled with the fact that patients in a capitation system mainly have a lower socioeconomic status.

\section{Comparison with existing literature}

As mentioned before, unlike in the present study, most studies focus on the association of unemployment and suicidal behaviour, not specifically on employment loss. ${ }^{27,20,29-32}$ Most of these studies also focus on current suicidal thoughts, which presumably leads to under-reporting of suicidal thoughts and behaviour. ${ }^{11,28}$ The present research asked about suicidal thoughts over the past 12 months, which is a more sensitive method. ${ }^{7.26}$ However, in this study the presence of suicidal thoughts required that a person had 'seriously' thought about committing suicide rather than merely having 'thoughts of death', as in some prior studies.

\section{Implications for research and practice}

The results of this study can be used in general practices: one of the major interventions a health professional can make to prevent suicide is ask about suicidal thoughts in high-risk patients. ${ }^{31-33}$ By taking into account social determinants, suicidal risk may be more easily recognised and faster action can be taken to provide the patient with proper treatment, guidance, and referral.

Economic crises place a great burden on health systems. Effects on health outcomes can be limited if public action compensates the threats. ${ }^{34}$ This study stresses the importance of continuous and reinforced assessment of suicidal risk in times of recession. Monitoring of people's health is essential.

In countries where primary care is accessible to all, GPs are in a privileged position to identify the health consequences of general societal problems. It allows them to properly assess the impact of stressful life events on people's health. In this respect, there is great potential for conducting more research at general practice level, but logistic and financial support is needed.

The questionnaire used in this study has proved to be a useful tool that could be used on a larger scale. Further research should focus on prospective data, in order to discover the real impact of employment loss on health and on the occurrence of suicidal thoughts and behaviour.

\section{Acknowledgements}

The authors would like to thank all responders for taking the time to fill out the questionnaires.

\section{Discuss this article}

Contribute and read comments about this article on the Discussion Forum: http://www.rcgp.org.uk/bjgp-discuss 


\section{REFERENCES}

1. Vlaams Agentschap Zorg \& Gezondheid. The number of suicides in Flanders increases. [Aantal zelfdodingen in Vlaanderen neemt toe]. 9 September 2011. http://uww.zorg-en-gezondheid.be/Nieuws/Aantal-zelfdodingen-in-Vlaanderenneemt-toe/ (accessed 23 Jul 2013).

2. Stuckler D, Basu S, Suhrcke M, et al. Effects of the 2008 recession on health: a first look at European data. Lancet 2011; 378(9786): 124-125

3. Scientific Institute of Public Health. OD Public Health and Surveillance. Sentinel general practitioners. http://www.wiv-isp.be/epidemio/epien/index10.htm laccessed 23 Jul 2013).

4. World Health Organization. The financial crisis and global health: report of a high-level consultation. Geneva: WHO, 2009.

5. World Health Organization. Impact of economic crises on mental health. Geneva: WHO. 2011.

6. Gehanno JF, Bulat P, Martinez-Jarreta B, et al. Undergraduate teaching of occupational medicine in European schools of medicine. Int Arch Occup Environ Health 2013; 19 April. [Epub ahead of print].

7. Borges G, Nock MK, Haro Abad JM, et al. Twelve-month prevalence of and risk factors for suicide attempts in the World Health Organization World Mental Health Surveys. J Clin Psychiatry 2010; 71(12): 1617-1628.

8. Gunnell D, Harbord R, Singleton N, et al. Factors influencing the development and amelioration of suicidal thoughts in the general population. Cohort study. $\mathrm{Br}$ $J$ Psychiatry 2004; 185: 385-393.

9. Van Der Heyden J, Gisle L, Demarest S, et al. Health interview survey in Belgium 2008. Report I - State of health. [Gezondheidsenquête België, 2008. Rapport I - Gezondheidstoestand]. Brussels: Operationele Directie Volksgezondheid en surveillance, 2009.

10. Goldney R, Wilson D, Dal Grande E. Suicidal ideation in a random community sample: attributable risk due to depression and psychosocial and traumatic events. Aust N Z J Psychiatry 2000; 34(1): 98-106.

11. Hintikka J, Pesonen T, Saarinen P, et al. Suicidal ideation in the Finnish general population. A 12-month follow-up study. Soc Psychiatry Psychiatr Epidemiol 2001; 36(12): 590-594.

12. Kjoller M, Helweg-Larsen M. Suicidal ideation and suicide attempts among adult Danes. Scand J Public Health 2000; 28(1): 54-61.

13. Paykel E, Myers J, Lindenthal J. Suicidal feelings in the general population: a prevalence study. Br J Psychiatry 1974; 124(0): 460-469.

14. Thomas $\mathrm{H}, \mathrm{Crawford} \mathrm{M}$, Meltzer $\mathrm{H}$. Thinking life is not worth living: a population survey of Great Britain. Soc Psychiatry Psychiatr Epidemiol 2002; 37(8): 351-356.

15. Weissman M, Bland R, Canino G. Prevalence of suicide ideation and suicide attempts in nine countries. Psychol Med 1999; 29(1): 9-17.

16. Gerkens S, Merkur S. Belgium: health system review. Health Syst Transit 2010; 12(5): 1-266.

17. Annemans L, Closon J-P, Closon M-C, et al. Comparison of the cost and quality of two financing systems for primary care in Belgium. [Vergelijking van kost en kwaliteit van twee financieringssystemen voor de eerstelijnszorg in België]. Health Services Research. (HSR). KCE Report 85A. Brussels: Federaal Kenniscentrum voor de Gezondheidszorg (KCE), 2008.

18. Denis B, Drielsma P. Which population is attending general practices operating a capitation system? Which is its use of primary health care? Research year 2009. [Quelle population suivons-nous dans les maisons médicales au forfait? Quelle est son utilisation de soins de médecine générale? Année étudiée 2009].
Brussels: Service d'Etude et De Recherche de la Fédération des Maisons Médicales et des Collectifs de Santé Francophones, 2011.

19. Kesteloot K, Gillet $P$, Filée D, et al. Financing the health centres: description of the activities and financial and economic analysis. [Financement des centres de santé: description des activités et analyse financière et économique]. Brussels: INAMI, ULg, KUL, CZV, 2003.

20. Nock MK, Borges G, Bromet EJ, et al. Cross-national prevalence and risk factors for suicidal ideation, plans and attempts. Br J Psychiatry 2008; 192(2): 98-105.

21. United Nations Educational, Scientific and Cultural Organization (UNESCO). Revision of the International Standard Classification of Education (ISCED). New York: UNESCO, 2011. http://wmw.uis.unesco.org/Education/Documents/ UNESCO_GC_36C-19_ISCED_EN.pdf (accessed 23 Jul 2013).

22. Boland B. Recommendation for good medical practice: global cardiovascular risk management. [Aanbeveling voor goede medische praktijkvoering. Globaal cardiovasculair risicobeheer]. Huisarts Nu 2007; 36: 339-369.

23. Garmyn B. Recommendation for good medical practice: breast cancer screening. [Aanbeveling voor goede medische praktijkvoering: Borstkankerscreening]. Huisarts Nu 2008; 37: 2-27.

24. Govaerts F. Recommendation for good medical practice: screening for colorectal cancer in persons without increased risk. [Aanbeveling voor goede medische praktijkvoering: Screenen op colorectale kanker bij personen zonder verhoogd risico]. Huisarts Nu 2008; 37: 341-361.

25. Groeneveld F. Standard of the Dutch Society of General Practitioners: the menopause. NHG-standaard De Overgang Huisarts Wet 2001; 10: 436-445.

26. Kessler RC, Berglund P, Nock M, et al. Trends in suicide ideation, plans, gestures, and attempts in the United States,1990-1992 to 2001-2003. JAMA 2005; 293(20): 2487-2495

27. Reynders A, Van Heeringen C, Demaeseneer J, Van Audenhove C. Study of explaining factors for the differences in suicide data in Flanders compared to other European countries. [Onderzoek naar verklarende factoren voor de verschillen in suïcidecijfers in Vlaanderen in vergelijking met Europese landen]. Lucas Leuven: KULeuven, 2009

28. Hintikka J, Koivumaa-Honkanen H, Lehto SM, et al. Are factors associated with suicidal ideation true risk factors? A 3-year prospective follow-up study in a general population. Soc Psychiatry Psychiatr Epidemiol 2009; 44(1): 29-33.

29. Caan W. Unemployment and suicide: is alcohol the missing link? Lancet 2009; 374(9697): 1241-1242.

30. Conwell Y, Duberstein PR, Caine ED. Risk factors for suicide in later life. Biol Psychiatry 2002; 52(3): 193-204.

31. Hawton K, Van Heeringen K. Suicide. Lancet 2009; 373(9672): 1372-1381.

32. Lundin A, Hemmingsson T. Unemployment and suicide. Lancet 2009; 374(9686): 270-271.

33. Gunnell D, Frankel S. Prevention of suicide: aspirations and evidence. BMJ 1994 308(6938): 1227-1233.

34. De Vos P, García-Fariñas A, Álvarez-Pérez A, et al. Public health services, an essential determinant of health during crisis. Lessons from Cuba, 1989-2000 Trop Med Int Health 2012; 17(4): 469-479. 